\title{
Case of vaccine-associated measles five weeks post- immunisation, British Columbia, Canada, October 2013
}

M Murti (michelle.murti@fraserhealth.ca) ${ }^{1}$, M Krajden $^{2}$, M Petric ${ }^{2}$, J Hiebert ${ }^{3}$, F Hemming ${ }^{1}$, B Hefford ${ }^{4}$, M Bigham $^{1}$, P Van Buynder $^{1}$

1. Fraser Health Authority, Surrey, British Columbia, Canada

2. Public Health Microbiology and Reference Laboratory British Columbia Centre for Disease Control, Vancouver, British Columbia, Canada

3. National Microbiology Laboratory, Public Health Agency of Canada, Winnipeg, Manitoba, Canada

4. 1-1400 George St., White Rock, British Columbia, Canada

Citation style for this article:

Murti M, Krajden M, Petric M, Hiebert J, Hemming F, Hefford B, Bigham M, Van Buynder P. Case of vaccine-associated measles five weeks post-immunisation, British Columbia, Canada, October 2013. Euro Surveill. 2013;18(49):pii=20649. Available online: http://www.eurosurveillance.org/ViewArticle.aspx?Articleld=20649

We describe a case of vaccine-associated measles in a two-year-old patient from British Columbia, Canada, in October 2013, who received her first dose of measlescontaining vaccine 37 days prior to onset of prodromal symptoms. Identification of this delayed vaccineassociated case occurred in the context of an outbreak investigation of a measles cluster.

In this report we describe a case of measles-mumpsrubella (MMR) vaccine-associated measles illness that was positive by both PCR and IgM, five weeks after administration of the MMR vaccine. Based on our literature review, we believe this is the first such case report which has implications for both public health follow-up of measles cases and vaccine safety surveillance.

Between 29 August and 2 September 2013, three unlinked persons from across the Fraser Valley, British Columbia, Canada, presented with rash illness consistent with clinical measles [1]. Based on the outbreak investigation by the local health authority, none of the three cases had an identified exposure to a measles case or travel history outside of Canada during the incubation period, and a source case was never identified. All three cases had the same measles genotype $B_{3}$ sequence type (MVs/British Columbia. CAN/34.13, MeaNS id 39928, GenBank accession numbers KF704002 and KF704001). Measles genotype B3 is endemic in the World Health Organization's African and Eastern Mediterranean regions [2]. Two additional cases of measles due to secondary transmission from one of the above cases were identified in British Columbia in the third week of September.

\section{Case report}

In early October 2013, a two-year-old child living in the Fraser Valley presented to the family physician with fever, rash, conjunctivitis and coryza. Symptoms had begun two days before, with a runny nose, followed by fever on the day hereafter. A macular rash appeared on the day of visiting the physician, starting on the face and progressing to the rest of the body; fever measured by the parents was at $39^{\circ} \mathrm{C}$.

Clinical examination of the child by the family physician found a fever of $39.5{ }^{\circ} \mathrm{C}$, marked bilateral conjunctivitis, and macular rash over the body. Three days later, fever had dissipated, rash was fading and symptoms resolved without complications.

Public health alerts had been issued to community physicians regarding the recent cluster of measles in September, which may have raised suspicion for measles in this case. Additionally, the child's family was aware of measles cases in the community from a relative who attended the same church as one of the original cases, but no direct link was identified and they had no travel history outside of Canada. Contact investigation revealed no ill household members or preschool contacts. The child's past medical history indicated anaphylaxis to peanuts and eggs. Primary series of immunisations were not up-to-date, as she had just received her first dose of MMR vaccine 37 days prior to the onset of illness. At the same visit, the child had received meningococcal $\mathrm{C}$ and pneumococcal conjugate vaccines.

\section{Laboratory investigations}

Laboratory testing for measles was performed on specimens collected on the day of rash onset. Measles RNA was detected in the nasopharyngeal swab by the RT-PCR assay [3]. Acute and convalescent measles specific IgM and IgG antibodies were detected in the blood by ELISA (Enzygnost Anti-Measles Virus IgM and IgG (Dade Behring, Marburg, Germany): IgM detectable (0.213), IgG $1294 \mathrm{mIU} / \mathrm{mL}$, and IgM detectable (0.246), $\operatorname{lgG} 2,413 \mathrm{mIU} / \mathrm{mL}$, respectively. Virus genotype was determined by the National Microbiology Laboratory in Winnipeg, Canada as vaccine strain, genotype A, MVs/ British Columbia/39.13 [A] (VAC) [4]. Other virology testing found no detectable Parvovirus B19 specific IgG or IgM antibody, and detectable human herpesvirus 
(HHV)-6 specific IgG antibody but no detectable HHV-6 DNA.

\section{Public health measures}

While genotyping results were pending, case management proceeded as for a wild-type measles infection. Public health follow-up lead to the identification of 87 contacts. As per guidelines, post-exposure prophylaxis was provided within six days of exposure to 45 susceptible contacts ( 41 contacts with a history of one dose of MMR vaccine received an additional MMR dose, and four contacts with no history of MMR vaccine or with contraindications to MMR vaccination, received immunoglobulin) [1]. All contacts received education on signs and symptoms of measles, and those who received immunoglobulin were recommended to subsequently receive MMR vaccine, if this was not contraindicated.

\section{Discussion}

The incubation period of measles is typically eight to 12 days from exposure to rash onset, with a range from seven to 21 days. Public health interventions are based on this established incubation period for determining the epidemiological links between cases and for estimating periods of exclusion for contacts in high risk settings $[5,6]$. Based on our review of the literature, this report documents the first case of MMR vaccineassociated measles, 37 days post-immunisation, well beyond 21 days and the routine 30 days post-MMR immunisation period used by the Canadian adverse event following immunization (AEFI) surveillance system.

Measles-containing vaccines are used globally, have been part of the British Columbia immunisation schedule since 1969, and have an impressive record of safety validated by careful, ongoing AEFI surveillance. Rash and/or mild clinical illness following MMR vaccine are not uncommon [7]. Clinically significant vaccine-associated illness is rare, but when it occurs it is indistinguishable from wild-type measles, except by genotyping [8]. Detection of vaccine virus has been documented up to 14 days post-immunisation by RT-PCR, and up to 16 days by immunofluorescence microscopy of urine sediment [9-12]. Complications from vaccine-associated measles have been documented in both immune-competent and compromised individuals $[13,14]$. Of note, only one case report of transmission from vaccineassociated measles has been identified $[15,16]$.

Possible explanations for this prolonged shedding of measles vaccine virus include interference with the immune response by host or vaccine factors. Immunoglobulin administration early in the incubation period has been reported to extend the time to onset of symptoms, but in this child there was no such history and no known immunosuppressive illness [5]. The two-fold rise between acute and convalescent measles-specific IgG suggests the vaccine-mediated immune response had been underway prior to the onset of symptoms. Investigations clarified that there were no shipping, handling or cold-chain deviations for the specific vaccine used, and that it was administered by a public health nurse trained in immunisations. The potential immunological impact of the older age of the child at the time of receiving the first dose of MMR vaccine, 33 months versus the typical 12-15 months of age, and the co-administration of meningococcal $\mathrm{C}$ and pneumococcal conjugate vaccines are areas for future investigation.

It is possible that the case's symptoms were not measles-vaccine-related but an inter-current illness confounding the presentation. However, symptoms of marked conjunctivitis, continued fever with rash, and progression of macular rash from face to the whole body, are all more suggestive of measles versus other exanthems caused by viral diseases. Parvovirus and HHV 6 results were negative, and the absence of intake of medications excludes a drug reaction. Rubella serology was not done as it was expected to be positive given the recent MMR vaccine administration. Therefore, the combination of classic measles symptoms, detection of measles vaccine virus and reactive measles IgM, and lack of evidence of an alternative illness explanation, were highly suggestive of measles vaccine-associated illness.

Heightened surveillance and awareness of measles because of the ongoing outbreak likely contributed to the identification of this case. Although this is the first such reported case, it likely represents the existence of additional, but unidentified, exceptions to the typical timeframe for measles vaccine virus shedding and illness. Such cases have important public health implications for the investigation of measles clusters because while there is uncertainty about case classification (wild-type vs vaccine-type), case and contact management should proceed as if for wild-type to prevent secondary transmission. In this case, uncertainty from the presence of a measles outbreak, symptom onset on day 37 after MMR vaccine administration, and a two-week period between the RT-PCR findings and genotype determination, resulted in the initially reasonable presumption that this was a wild-type measles case and subsequent resource-intense follow-up of contacts. Awareness of the frequency of such exceptions to the typical measles timeframe and improving the timeliness of measles vaccine virus genotyping could help focus public health resources on cases of wild-type measles. Further investigation is needed on the upper limit of measles vaccine virus shedding based on increased sensitivity of the RT-PCR-based detection technologies and the immunological factors associated with vaccine-associated measles illness and virus shedding.

\section{Acknowledgements}

We would like to thank the patient and their family, as well as the FHA public health nurses, Stephanie Konrad, Monika Naus, and David Puddicombe for their assistance. 
None declared.

\section{Authors' contributions}

$\mathrm{BH}, \mathrm{FH}, \mathrm{MM}$ and PVB contributed to the clinical and public health management of the case. MK, MP and JH provided laboratory testing. MM drafted the manuscript; all authors critically revised and approved the final version of the manuscript.

\section{References}

1. British Columbia Centre for Disease Control (BCCDC) Communicable Disease Control Manual, Measles. British Columbia: BCCDC. 2011. Available from: http://www.bccdc.ca/ $\mathrm{NR} /$ rdonlyres/9C53A1ED-4C45-4E44-8E93-9626C7FECF5E/o/ Measles_June30.pdf

2. World Health Organization (WHO). Immunization surveillance, assessment and monitoring. Measles surveillance data. Geneva: WHO. [Accessed 6 Nov 2013. Available from: http:// www.who.int/immunization_monitoring/diseases/measles monthlydata/en/index1.html

3. Hummel KB, Lowe L, Bellini WJ, Rota PA. Development of quantitative gene-specific real-time RT-PCR assays for the detection of measles virus in clinical specimens. J Virol Methods. 2006;132(1-2). 166-73. http://dx.doi.org/10.1016/j. jviromet.2005.10.006. PMid:16274752.

4. World Health Organization (WHO). Measles Virus Nomenclature Update: 2012. Wkly Epidemiol Rec. 2012;87(9):73-81. PMid:22462199.

5. Strebel P, Hersh B. Measles. In: Heymann DL, editors. Control of Communicable Diseases Manual 19th ed. Washington: American Public Health Association; 2008:402-8.

6. American Academy of Pediatrics. Measles. In: Pickering LK, editor. Red Book: 2012 Report of the Committee on Infectious Diseases 29th ed. Elk Grove Village: American Academy of Pediatrics; 2012:489-99.

7. GlaxoSmithKline. Priorix $®$ Product Information.

GlaxoSmithKline; 20 Jul 2006. Available from: http://www.gsk. com.au/resources.ashx/vaccineproductschilddataproinfo/71/ FileName/BAE7Fo42FCEF2334B067DBA93401BF6A/PI_Priorix. pdf

8. Berggren KL, Tharp M, Boyer KM. Vaccine-associated "wildtype" measles. Pediatr Dermatol. 2005;22(2):130-2. http:// dx.doi.org/10.1111/j.1525-1470.2005.22208.x. PMid:15804301.

9. Kaic B, Gjenero-Margan I, Aleraj B, Vilibić-Čavlek T,

Santak M, Cvitković A, et al. Spotlight on measles 2010: Excretion of vaccine strain measles virus in urine and pharyngeal secretions of a child with vaccine associated febrile rash illness, Croatia, March 2010. Euro Surveill. 2010;15(35):pii=19652. Available from: http://www. eurosurveillance.org/ViewArticle.aspx?Articleld=19652. PMid:20822734.

10. Morfin F, Beguin A, Lina B, Thouvenot D. Detection of measles vaccine in the throat of a vaccinated child. Vaccine. 2002;20(1112):1541-3. http://dx.doi.org/10.1016/S0264-410X(01)00495-9

11. Llanes-Rodas R, Liu C. Rapid diagnosis of measles from urinary sediments stained with fluorescent antibody. N Engl J Med. 1966;275:516-23. http://dx.doi.org/10.1056/ NEJM196609082751002. PMid:5331291.

12. Rota PA, Khan AS, Durigon E, Yuran T, Villamarzo YS, Bellini WJ. Detection of measles virus RNA in urine specimens from vaccine recipients. J Clin Microbiol. 1995;33(9):2485-8. PMid:7494055. PMCid:PMC228449.

13. Monafo WJ, Haslam DB, Roberts RL, Zaki SR, Bellini WJ, Cofin CM. Disseminated measles infection after vaccination in a child with a congenital immunodeficiency. J Pediatr. 1994;124(2):273-6. http://dx.doi.org/10.1016/ So022-3476(94)70318-3

14. Bitnun A, Shannon P, Durward A, Rota PA, Bellini WJ, Graham $C$, et al. Measles inclusion-body encephalitis caused by the vaccine strain of measles virus. Clin Infect Dis. 1999;29(4):855 61. http://dx.doi.org/10.1086/520449. PMid:10589903.

15. Millson D. Brother-to-sister transmission of measles after measles, mumps, and rubella immunisation. Lancet. 1989; 1(8632):271. http://dx.doi.org/10.1016/S0140-6736(89)91274-9

16. Hau M, Schwartz KL, Frenette C, Mogck I, Gubbay JB, Severini $A$, et al. Local public health response to vaccine-associated measles: case report. BMC Public Health. 2013;13:269. http://dx.doi.org/10.1186/1471-2458-13-269. PMid:23531102. PMCid:PMC3623646. 